\title{
STUDY OF BIODEGRADATION, BIOCOMPATIBILITY AND BACTERICIDAL ACTIVITY OF FILM MATERIALS WITH TIAMULIN FUMARATE BASED ON POLYURETHANEUREA
}

\author{
Tetiana Vislohuzova ${ }^{1}{ }^{凶}$, Rita Rozhnova ${ }^{1}$, Natalia Galatenko ${ }^{1}$, \\ Larysa Narazhayko', Ada Rudenko ${ }^{2}$
}

https://doi.org/10.23939/chcht14.03.318

\begin{abstract}
The influence of the model biological medium 199 on the structure and properties of film materials with tiamulin fumarate based on polyurethaneurea containing in its structure the hydrophilic fragments of the copolymer of $\mathrm{N}$-vinylpyrrolidone with vinyl acetate and vinyl alcohol has been investigated. According to IR spectroscopy, under the influence of the biological medium 199 there are processes of biodegradation of polymer materials which are accompanied by a decrease in the intensity of the absorption band $v_{\mathrm{C}=\mathrm{O}}$ of vinylpyrrolidone ring. It is established that the introduction of tiamulin fumarate into polyurethaneurea facilitates their biodegradation, as evidenced by a decrease of the tensile strength (1.28-2.38 times) and a relative elongation at break (1.36-1.82 times) after incubation in the biological medium 199 by physicomechanical tests. The tissue culture method has established the biocompatibility of film materials with tiamulin fumarate. According to the results of microbiological studies, bactericidal properties were observed in relation to the bacteria Staphylococcus aureus and Escherichia coli. It allows using them for production of drainage in abdominal surgery.
\end{abstract}

Keywords: polyurethaneurea, tiamulin fumarate, $\mathrm{N}$-vinylpyrrolidone, copolymer, vinyl acetate, vinyl alcohol, model biological medium 199.

\section{Introduction}

The polyurethaneurea (PUU) with fragments of the copolymer of $N$-vinylpyrrolidone with vinyl acetate and vinyl alcohol (VP-VA) are of particular importance among polymer materials of medical use thanks to biocompatibility, increased hydrophilicity and ability to

\footnotetext{
${ }^{1}$ Institute of Macromolecular Chemistry of the NAS of Ukraine, 48, Kharkivske shose, 02160 Kyiv, Ukraine

${ }^{2}$ Institute of Urology of the National Academy of Medical Sciences of Ukraine,

9a, V. Vynnychenka St., 04053 Kyiv, Ukraine

凶rudenchyk@gmail.com

(c) Vislohuzova T., Rozhnova R., Galatenko N., Narazhayko L., Rudenko A., 2020
}

promote the prolonged release of drug substances from a polymer matrix [1-3]. Therefore, it is expedient to use them as polymer matrix for medicine biologically active composite materials.

Considering the aforesaid, PUU based on diisocyanate prepolymer (DPP), 1,6-hexamethylenediamine (HMDA) as a macrochain extender, the VP-VA copolymer at different percentage ratio of diamine to copolymer [4] and bioactive film materials with tiamulin fumarate on their basis [5] have been synthesized. Tiamulin fumarate is an antibiotic, which is a semisynthetic derivative of the natural origin of an antibiotic pleuro-mutilin, which is active to gram-positive microorganisms and mycoplasma $[6,7]$ :

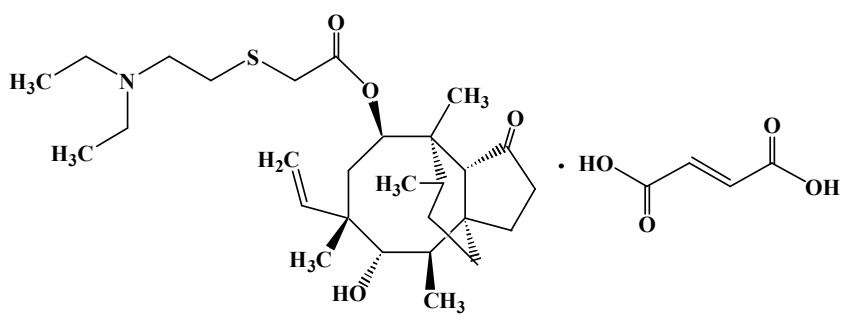

One of the most important characteristics of polymers of medical use is its ability to biodegradation in the conditions imitating the environment of the organism as this process can influence the quantity of released drug substance to the internal environment of an organism. The results of the researches in vitro will allow predicting behavior of polymer materials at their further application in medical practice.

Thus, the authors [8] have conducted research of the biodegradation of polymer materials with Amison based on a block-copolyurethane containing the fragments of VP-VA copolymer in the structure. The stability of the studied samples in the model medium as a result of Amizon presence was established.

The investigations of the influence of the model biological medium on the structure and properties of PUU with Decamethoxin containing VP-VA copolymer fragments in the structure have been carried out. The 
beginning of the processes of biodegradation is accompanied by a decrease in the elasticity of the samples and a decrease in the intensity of $v_{\mathrm{C}=0}[9]$.

It is known that the biodegradation processes are influenced by the chemical composition including a ratio of links of monomers, possible influence of drug substances [10]. Therefore, for confirmation of the offered field of use of the developed film materials with tiamulin fumarate as devices of medical use it is expedient to investigate the influence of the model biological medium on their structure and properties.

The purpose of the work is to study the biodegradation of PUU with copolymer VP-VA and HMDA fragments and film materials with tiamulin fumarate obtained on their basis as well as to study their bactericidal activity and biocompatibility.

\section{Experimental}

\subsection{Materials}

The PUU with VP-VA copolymer and HMDA fragments in the structure synthesized for different percentages ratio of HMDA:VP-VA (40:60; 50:50; 60:40; 70:30) and film materials filled by tiamulin fumarate (in the amount of $1 \mathrm{wt} \%$ ) on their basis were objects of researches [4, 5]. Biological medium 199 was used as a model medium (BM 199) (BioTestLab, Ukraine, pH 7.4-7.7).

\subsection{The Method of Incubation in $\mathrm{BM} 199$}

Samples of PUU in the form of $0.5 \times 5.0 \mathrm{~cm}$ strips were placed in sterile tubes, adding $25 \mathrm{ml}$ of a model biological medium, and kept in a thermostat at the temperature of $(310 \pm 1) \mathrm{K}$ for 1,3 and 6 months. Solutions of model mediums were changed daily. After defined incubation terms in the model medium, the samples were taken out, washed with distilled water and dried to a constant mass at $T=343 \mathrm{~K}$.

\subsection{Study Methods}

\subsubsection{Fourier Transforms Infrared (ATR FT-IR)}

The absorption spectra in the range of $650-4000 \mathrm{~cm}^{-1}$ were measured on a Tensor-37 FTIR spectrometer by the MATR method with the aid of a diamond crystal trapezoidal prism (a number of reflections of $N=1$, an incidence angle of $\varphi=39^{\circ}$ ). The absorption bands were assigned as described in [11].

\subsubsection{Mechanical tests}

The physico-mechanical properties such as tensile strength at break $(\sigma, \mathrm{MPa})$ and relative elongation at break $(\varepsilon, \%)$ of the PUU were determined on the tension testing machine P5 according to the standards.
The tensile strength at break was calculated using the expression:

$$
\sigma=\frac{F_{\max }}{b \cdot h}
$$

where $F_{\max }$ is a maximum load at break of sample, $\mathrm{H} ; b$ is a sample width, mm; $h$-thickness of sample, $\mathrm{mm}$.

The relative elongation at break was calculated using the expression:

$$
E=\frac{\Delta l}{l} \cdot 100
$$

where $\Delta l$ is an absolute elongation of sample at break, $\mathrm{mm} ; l$ is an initial length of sample, $\mathrm{mm}$.

\subsubsection{Tissue culture studies}

By tissue culture method the study of biocompatibility of these materials on the culture of tissue of subcutaneous fatty tissue of white laboratory rats which in the conditions of cultivation causes the growth of fibroblastic and fibroblast-like elements, was conducted [12]. The culture of tissues was received by explantation of pieces of subcutaneous fatty tissue. It was placed in Carrel flacon with a nutritious mixture consisting of the biological medium 199 and chicken plasma. In Carrel flacon the samples of studied polymer materials in the size of $0.5 \times 0.5 \mathrm{~cm}$ were introduced. Then an embryonic extract was added and a plasma clot (a solid phase) was obtained. After the formation of the solid phase (10$15 \mathrm{~min}$ ) the biological medium 199 and the serum of cattle (a liquid phase) was introduced. Cultivations were carried out at the temperature of $310 \mathrm{~K}$. Flacons with explants of subcutaneous fatty tissue without the addition of polymer samples were used as control.

The change of the liquid phase of the nutrient medium and the study of growth and development of cellular elements of the subcutaneous fatty tissue of white rats both in the control and experimental groups after 3, 7, 10 and 14 days of cultivation were carried out. The cultures were investigated under a microscope in a native state and stained with haematoxylin-eosin and picrofucsin. For the purpose of standardization of the nature of growth of cultures, their zones were classified as a compact zone, a mesh-like zone and a zone of migratory cells. The criterion for distinguishing of these zones was the nature of the location of growing fibroblastic elements.

\subsubsection{Microbiological tests}

Microbiological tests studied the bactericidal activity of film materials in relation to the most widespread gram-positive and gram-negative bacteria that contaminated the surface of the wound, causing its infectious lesion. The researches were conducted using the disco-diffusion method according to the recommendations of the European Committee on Antimicrobial Suscep- 
tibility Testing (EUCAST). Disks (samples of the studied film materials) were placed in the Petri dish with nutrient medium, and the microbial loading was $5 \cdot 10^{7}$ colony forming units in $1 \mathrm{ml}$. Calculations were carried out after an incubation of crops in the thermostat at the temperature of $309.6 \mathrm{~K}$ from 1 to $48 \mathrm{~h}$. The bactericidal action of samples was evaluated by the presence or absence of microbial growth under and around the disks, which is a result of the diffusion of tiamulin fumarate. When zones of growth inhibition around the disks were visually measured, the attention was directed to the zones of full inhibition of microorganisms growth. The diameter of the zones of growth inhibition was measured with the accuracy of $1 \mathrm{~mm}$.

\section{Results and Discussion}

The ability to biodegradation of polymer materials with VP-VA copolymer fragments in the structure after their incubation in the model biological medium was investigated by IR spectroscopy method and by changing their physico-mechanical parameters before (control) and after incubation in BM 199 for 1, 3 and 6 months.

\subsection{Mechanical Tests}

Physico-mechanical tests, namely changes in tensile strength $(\sigma, \mathrm{MPa})$ and relative elongation at break $(\varepsilon, \%)$ of polymer systems based on DPP, HMDA, VP-VA and tiamulin fumarate $(1 \mathrm{wt} \%)$ obtained at different percentage ratio of HMDA:VP-VA (40:60; 50:50; 60:40; 70:30) after an incubation in the model biological medium for 1, 3 and 6 months have been conducted.

According to the results of physico-mechanical properties studies after incubation in the BM 199 of PUU with VP-VA copolymer fragments without tiamulin fumarate there is a slight increase of tensile strength at break after 1 month of incubation (Table 1).
The tensile strength at break of PUU with fragments of VP-VA copolymer before the incubation in the BM 199 are in the range of $1.9-2.8 \mathrm{MPa}$, whereas after 6 months of incubation - in the range of 1.54.1 MPa (Table 1). Thus, after 6 months of incubation in the BM 199 of PUU with VP-VA copolymer fragments there is an increase of tensile strength at break compared with the control. The exception is PUU with maximum content of VP-VA copolymer in the structure (synthesized by the percentage ratio of HMDA:VP-VA $=40: 60$ ), which lose strength characteristics by 1.27 times after 6 months of incubation. Thus, a tendency has been revealed -increasing the content of copolymer in the structure of PUU leads to increase in the tensile strength at break to a lesser extent, and at the maximum amount of copolymer $(60 \%)$ its decrease occurs.

The tensile strength at break of film material containing tiamulin fumarate in its composition, based on PUU with VP-VA copolymer fragments before the incubation in the BM 199 is $3.0-7.3 \mathrm{MPa}$, whereas after 6 months of incubation it is 1.9-4.3 MPa (Table 1). That is the decrease of the tensile strength at break of all samples by $1.28-2.38$ times is observed.

Relative elongation at break of PUU with VP-VA copolymer fragments before the incubation in the BM 199 are in the range of $27-46 \%$, whereas after 6 months of incubation - in the range of $22-81 \%$ (Table 2). For PUU with the minimum content of the VP-VA copolymer in the structure (synthesized by the percentage ratio of HMDA:VP-VA = 70:30) during the incubation in BM 199 there is an increase in relative elongation at break. With an increase in the content of copolymer in the structure of the PUU after 6 months of incubation there is a decrease of the relative elongation at break by $1.23-1.73$ times.

Relative elongation at break of all film materials with tiamulin fumarate after incubation in the BM 199 also decreases, starting from 1 month of incubation (Table 2). There is a decrease in the relative elongation at break by 1.36-1.82 times after 6 months of incubation.

Table 1

\section{Tensile strength at break of PUU for different ratio of HMDA:VP-VA after incubation in BM 199}

\begin{tabular}{|c|c|c|c|c|c|}
\hline \multirow{2}{*}{ Samples } & \multirow{2}{*}{ HMDA/VP-VA, $\%$} & \multicolumn{4}{|c|}{ Tensile strength at break, $\mathrm{MPa}$} \\
\hline & & control & 1 month & 3 months & 6 months \\
\hline \multirow{4}{*}{$\mathrm{DPP}+\mathrm{HMDA}+\mathrm{VP}-\mathrm{VA}$} & $40: 60$ & 1.9 & 2.1 & 2.1 & 1.5 \\
\hline & $50: 50$ & 1.6 & 2.3 & 2.3 & 2.1 \\
\hline & $60: 40$ & 2.0 & 2.5 & 2.8 & 2.7 \\
\hline & $70: 30$ & 2.8 & 3.7 & 4.0 & 4.1 \\
\hline \multirow{4}{*}{$\mathrm{DPP}+\mathrm{HMDA}+\mathrm{VP}-\mathrm{VA}+$ tiamulin fumarate } & $40: 60$ & 5.7 & 2.3 & 1.7 & 2.4 \\
\hline & $50: 50$ & 3.0 & 1.5 & 2.5 & 1.9 \\
\hline & $60: 40$ & 4.1 & 2.1 & 3.0 & 3.2 \\
\hline & $70: 30$ & 7.3 & 3.6 & 4.4 & 4.3 \\
\hline
\end{tabular}


Table 2

Relative elongation at break of PUU for different ratio of HMDA:VP-VA after incubation in BM 199

\begin{tabular}{|c|c|c|c|c|c|}
\hline \multirow{2}{*}{ Samples } & \multirow{2}{*}{ HMDA/VP-VA, \% } & \multicolumn{4}{|c|}{ Relative elongation at break, $\%$} \\
\hline & & control & 1 month & 3 months & 6 months \\
\hline \multirow{4}{*}{ DPP+HMDA+VP-VA } & $40: 60$ & 38 & 43 & 29 & 22 \\
\hline & $50: 50$ & 27 & 39 & 34 & 22 \\
\hline & $60: 40$ & 37 & 42 & 32 & 29 \\
\hline & $70: 30$ & 46 & 80 & 73 & 81 \\
\hline \multirow{4}{*}{$\mathrm{DPP}+\mathrm{HMDA}+\mathrm{VP}-\mathrm{VA}+$ tiamulin fumarate } & $40: 60$ & 72 & 56 & 45 & 52 \\
\hline & $50: 50$ & 43 & 29 & 31 & 28 \\
\hline & $60: 40$ & 61 & 41 & 40 & 45 \\
\hline & $70: 30$ & 100 & 72 & 76 & 55 \\
\hline
\end{tabular}

Thus, the effect of the concentration of VP-VA copolymer in the structure of PUU on their physicomechanical properties after incubation in the BM 199 was detected. For PUU with a minimum content of copolymer under the influence of BM 199 there is an increase of strength characteristics, while increasing the content of the copolymer causes a decrease of strength (at $60 \%$ of VP-VA) and relative elongation at break (from $40 \%$ of VP-VA). For film materials with tiamulin fumarate based on PUU with fragments of copolymer VP-VA in the structure there is a decrease of tensile strength and relative elongation at break of all investigated samples. It allows concluding that the introduction of tiamulin fumarate into the PUU contributes to their biodegradation, which is probably due to release of tiamulin fumarate from the polymer matrix.

\subsection{Spectroscopic Investigations}

In order to determine the influence of BM 199 on the structure of investigated polymer materials, IRspectroscopic investigations of samples before the incubation (control) and samples after incubation in BM 199 were conducted. To detect the influence of tiamulin fumarate on the process of biodegradation of film materials, infrared spectra of PUU with fragments of VPVA copolymer in the structure and film materials with tiamulin fumarate on their basis were removed. To detect the influence of the chemical composition on the process of biodegradation of polymer materials, the infrared spectra of PUU synthesized for different percentages ratio of component were removed.

The IR-spectra of the PUU with VP-VA copolymer fragments synthesized at different percentage ratio of components $(40: 60 ; 50: 50 ; 60: 40 ; 70: 30)$, and film materials with tiamulin fumarate obtained on their basis were measured.

Fig. 1 shows infrared spectra of PUU with VP-VA copolymer fragments in the structure synthesized by the percentage ratio of HMDA:VP-VA $=70: 30$ before and after incubation in BM 199. By comparing these spectra, it is revealed that specified PUU remained unchanged after the incubation in the BM 199.

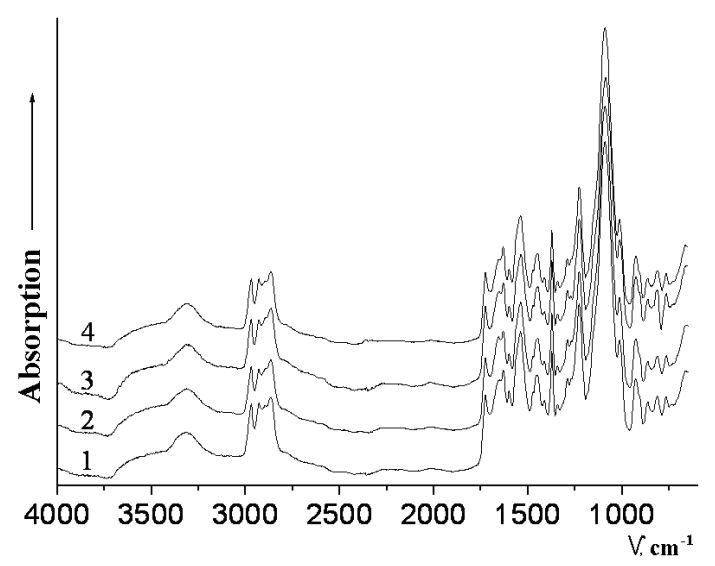

Fig. 1. IR-spectra of DPP+HMDA+VP-VA (70:30) before (1) and after incubation in BM 199 for 1 month (2); 3 months (3) and 6 months (4)

On the infrared spectra of film materials with tiamulin fumarate which are received based on PUU with VP-VA copolymer fragments in the structure at the percentage ratio of HMDA:VP-VA $=70: 30$ after incubation in BM 199 there is a decrease of intensity of the absorption band $v_{\mathrm{NH}-\text { free }}$ with the approximate maximum of $3506 \mathrm{~cm}^{-1}$ and narrowing of the absorption band $v_{\mathrm{NH}-\mathrm{bond}}$ with the maximum of $3316 \mathrm{~cm}^{-1}$ with a simultaneous increase of its intensity (Fig. 2). It demonstrates an increase in the number of $\mathrm{NH}$ groups bound by hydrogen bonds. The intensity of the absorption band $v_{\mathrm{C}=\mathrm{O}}$ of vinylpyrrolidone ring with the maximum of $1660 \mathrm{~cm}^{-1}$ during incubation in the model biological medium gradually decreases, and the intensity of the absorption band deformation vibrations of $\mathrm{NH}$ groups with the maximum of $1632 \mathrm{~cm}^{-1}$ increases (Fig. 2). It is connected with the increase in the number of $\mathrm{NH}$ groups on the surface of the samples due to spatial changes in the surface layer molecules (as IR spectra are removed from the surface of polymer materials). 


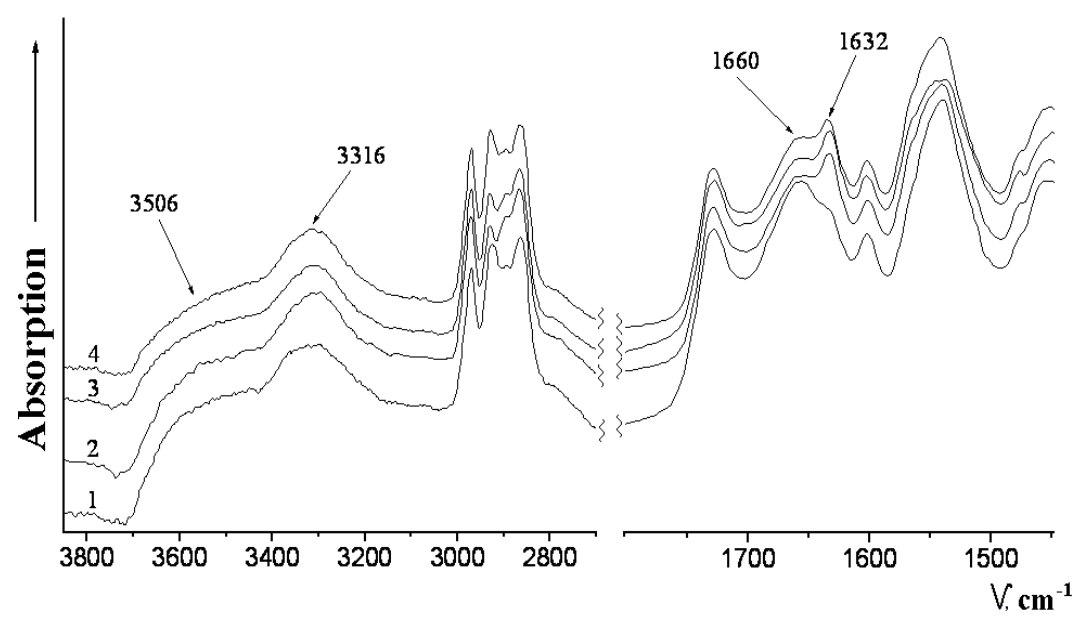

Fig. 2. IR-spectra of DPP+HMDA+VP-VA (70:30) with tiamulin fumarate before (1) and after incubation in BM 199 for 1 month (2); 3 months (3) and 6 months (4)

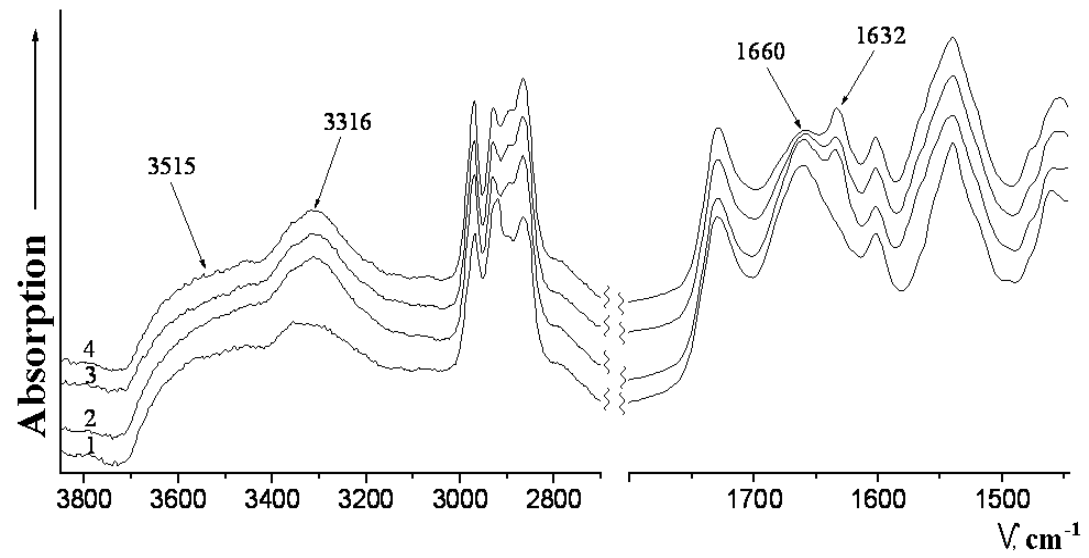

Fig. 3. IR-spectra of DPP+HMDA+VP-VA (50:50) before (1) and after incubation in BM 199 for 1 month (2); 3 months (3) and 6 months (4)

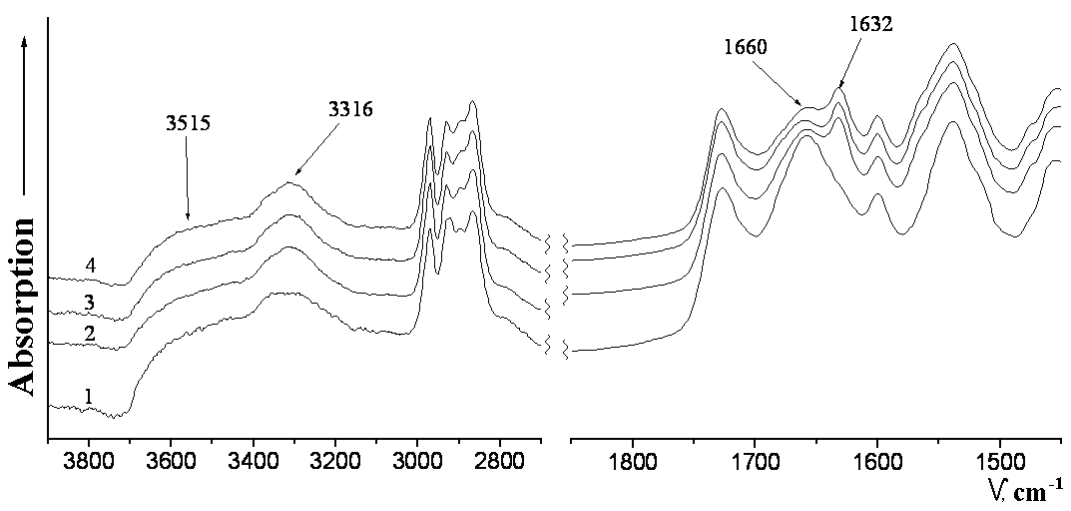

Fig. 4. IR-spectra of DPP+HMDA+VP-VA (50:50) with tiamulin fumarate before (1) and after incubation in BM 199 for 1 month (2); 3 months (3) and 6 months (4)

After incubation in the BM 199 on the infra-red spectra of PUU with VP-VA copolymer fragments synthesized by the percentage ratio of HMDA:VP-VA =
$=50: 50$ and on the infra-red spectra of film materials with tiamulin fumarate obtained based on these PUU the changes are identical. The infra-red spectra demonstrate 
the decrease of the intensity of the absorption band $v_{\mathrm{NH}-\text { free }}$ with the approximate maximum at $3515 \mathrm{~cm}^{-1}$ (for unfilled PUU) (Fig. 3) and $3506 \mathrm{~cm}^{-1}$ (for film materials with tiamulin fumarate) (Fig. 4), the narrowing of the absorption band $v_{\mathrm{NH}-b o n d}$ with the maximum at $3316 \mathrm{~cm}^{-1}$ with a simultaneous increase its intensity (Figs. 3 and 4), the decrease in the absorption band $v_{\mathrm{C}=\mathrm{O}}$ of vinylpyrrolidone ring with the maximum at $1660 \mathrm{~cm}^{-1}$ and the increase of the intensity of the absorption band deformation vibrations of $\mathrm{NH}$ groups with the maximum at $1632 \mathrm{~cm}^{-1}$ (Figs. 3 and 4).

Thus, according to the results of IR spectroscopy, we can conclude that after incubation of the studied materials in the BM 199 there is a decrease of intensity of the absorption band $v_{\mathrm{NH}-\text { free }}$ and narrowing of the absorption band $v_{\text {NH-bond }}$ with a simultaneous increase of its intensity (for PUU (50:50) and all film materials with tiamulin fumarate). It demonstrates an increase in the number of $\mathrm{NH}$ groups bound by hydrogen bonds. There is also a decrease of the intensity of the absorption band $v_{\mathrm{C}=\mathrm{O}}$ of vinylpyrrolidone ring, which obviously indicates the processes of biodegradation and increase of the intensity of the absorption band deformation vibrations of $\mathrm{NH}$ groups (for PUU (50:50) and all film materials with tiamulin fumarate), which is connected with increase in the number of $\mathrm{NH}$ groups on the surface of the samples due to spatial changes in the surface layer molecules (as infrared spectra are removed from the surface of polymer materials). Thus, the results of the studies allowed determining the dependence of the above-mentioned changes from the presence of tiamulin fumarate in the composition of PUU and from the concentration of VPVA copolymer in their structure. The changes on the infrared spectra are observed for samples of PUU with high content copolymer in the structure $(50 \%)$ and for all film materials with tiamulin fumarate.

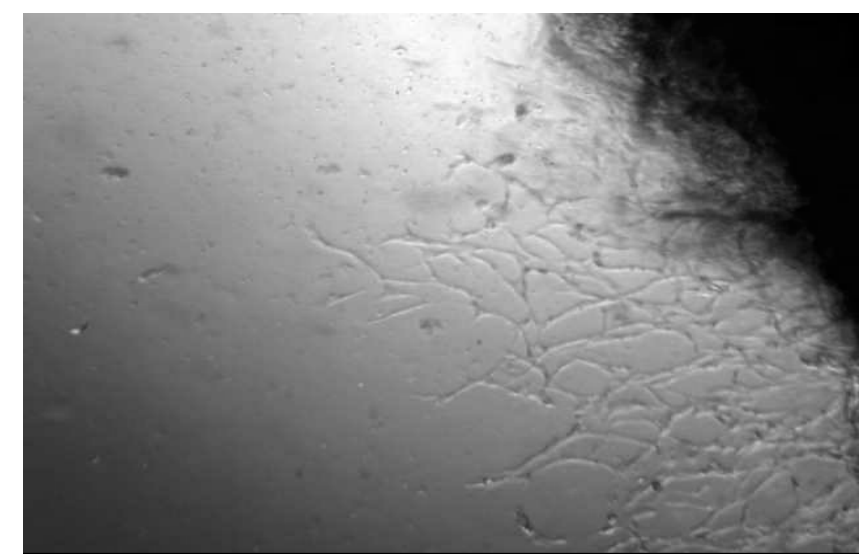

a)

\subsection{Tissue Culture Studies}

To study the biocompatibility of polymer materials and the influence of prolonged form of tiamulin fumarate on the growth and development of the culture of fibroblastic elements researches were conducted by tissue culture method.

The objects of research were PUU with fragments of VP-VA copolymer in structure synthesized for the ratio of HMDA:VP-VA $=70: 30$ and polymer materials with tiamulin fumarate obtained on their basis. Flacons with explants of subcutaneous fatty tissue without the addition of polymer samples were used as control.

According to the results, on the $3^{\text {rd }}$ day of cultivation the beginning of growth of fibroblastic elements was observed. Both in control flacons and in flacons with a polymer sample without tiamulin fumarate the beginning of growth was represented by the formation of single cells of elongated form and by the single migrating fibroblastic elements, which had a spindleshaped form (Fig. 5a).

For the samples of film materials with tiamulin fumarate migration of fibroblastic elements in Carrel flacons also began on the $3^{\text {rd }}$ day, but distinct from the control flacons there were single cells of irregular round form (Fig. 5b).

On the $7^{\text {th }}$ day of cultivation in both flacon with a polymer sample without tiamulin fumarate and in flacon with a film material with tiamulin fumarate (Figs. 6b, 6c) there was the formation of three growth zones. It is a compact zone consisting of cells of spindle-shaped and polygonal form, a mesh-like zone consisting of bunches and thread-like structures of cells located in a grid, and zones of single migratory elements of the spindle-shaped and polygonal form. The surface of growth and external characteristics of cells did not differ significantly from the control samples (Fig. 6a).

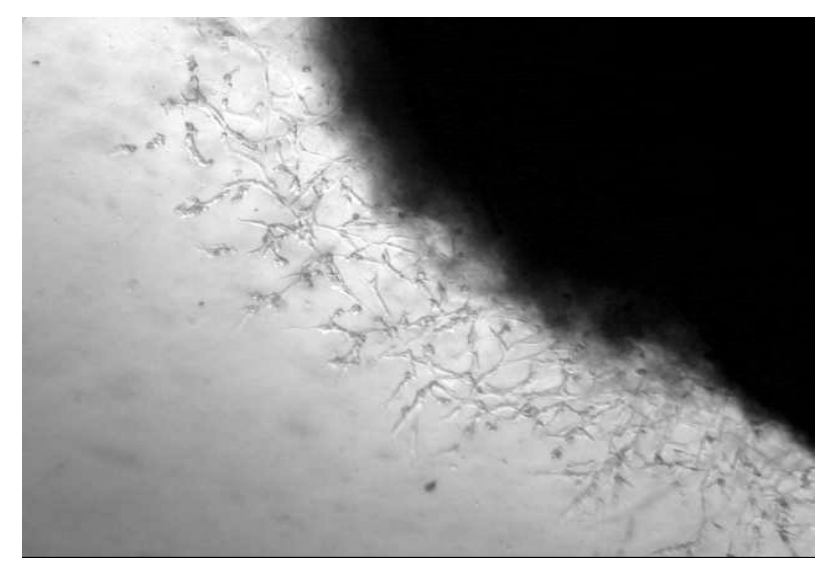

b)

Fig. 5. The beginning of growth on the culture of subcutaneous fatty tissue of rats on the $3^{\text {rd }}$ day of cultivation in flacon with control (a) and in flacon with film material with tiamulin fumarate (b) 


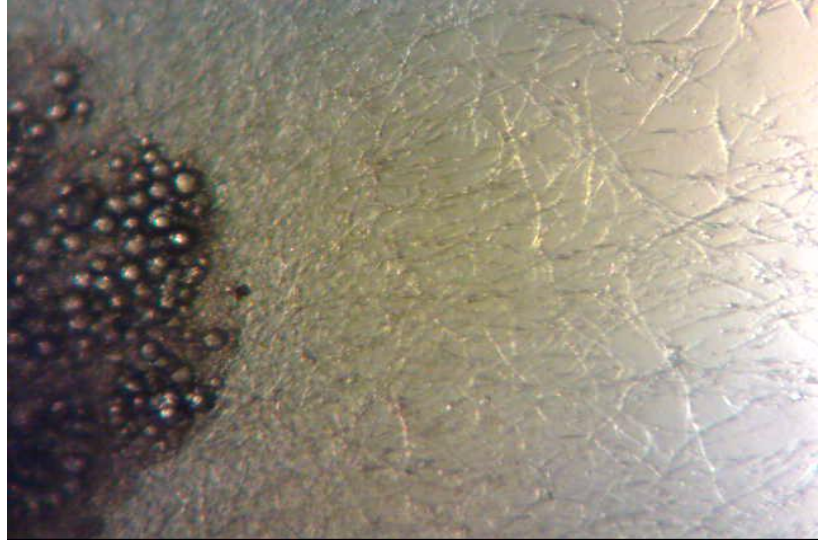

a)

Fig. 6. Growth of tissue culture of fibroblasts on the $7^{\text {th }}$ day of cultivation in a flacon with control (a), in a flacon with a polymer material without tiamulin fumarate (b), and in a flacon with a film material with tiamulin fumarate (c)

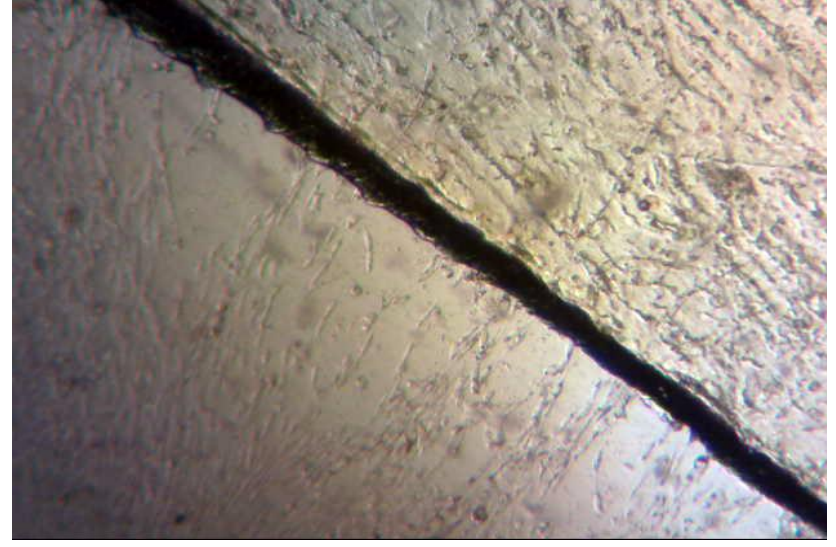

b)

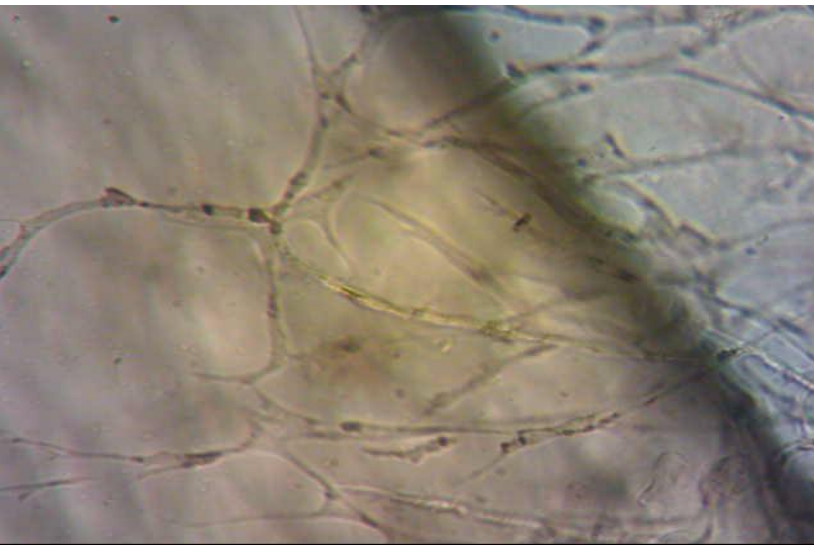

c)

For the polymer sample with tiamulin fumarate, growth of cell under the surface of the polymer sample is also observed. Separately lying cells of polygonal form are found larger in size than in the control. There were signs of the beginning of degenerative changes in the compact and meshlike zones (Fig. 7b), whereas for control samples the signs of degenerative changes were only in the compact zone.

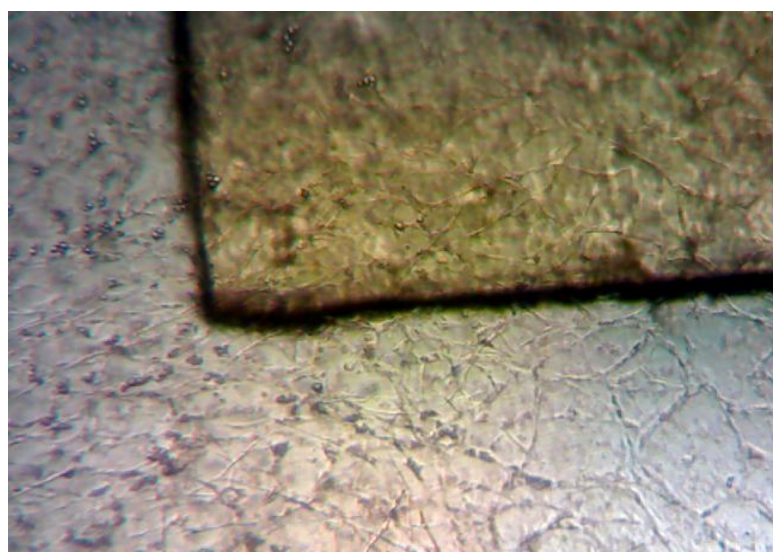

b)

a)

Fig. 7. Growth of the culture of fibroblasts and the beginning of degenerative changes on the 10th day in flacon with control (a) and in flacon with film material with tiamulin fumarate (b) 


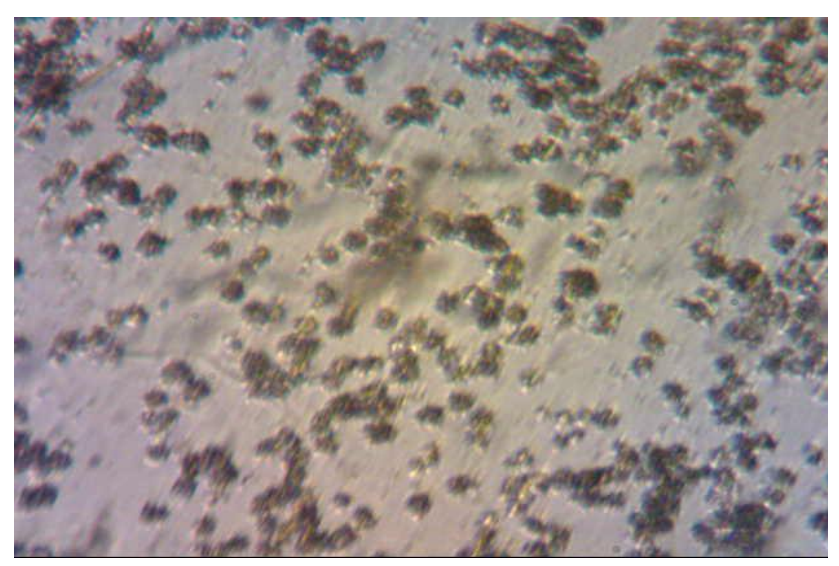

a)

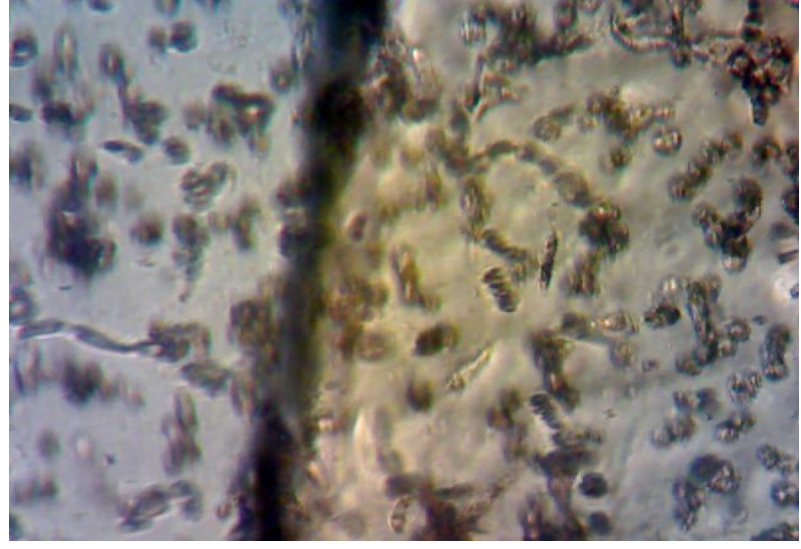

b)

Fig. 8. Degenerative changes in the culture of fibroblasts on the 14th day in flacon with control (a) and in flacon with film materials with tiamulin fumarate (b)

On the $14^{\text {th }}$ day, the cell population in all flacons entered the phase of expressed degeneration, which manifests itself in considerable vacuolization of the cytoplasm and its granular rebirth in the cells. It corresponds to the dynamics of growth and development of tissue culture of fibroblasts for this period (Fig. 8).

Thus, according to the results of researches by tissue culture method, the culture of fibroblasts cultivated with polymer materials with tiamulin fumarate and without a drug substance is in a stable growth stage, as well as the control one. Taking into account the absence of significant changes in the growth and development of cellular elements for all investigated samples in comparison with the control ones, we can conclude that there is no toxic effect of the studied materials on cultured cells. Therefore, the samples of film materials can be characterized as biocompatible.

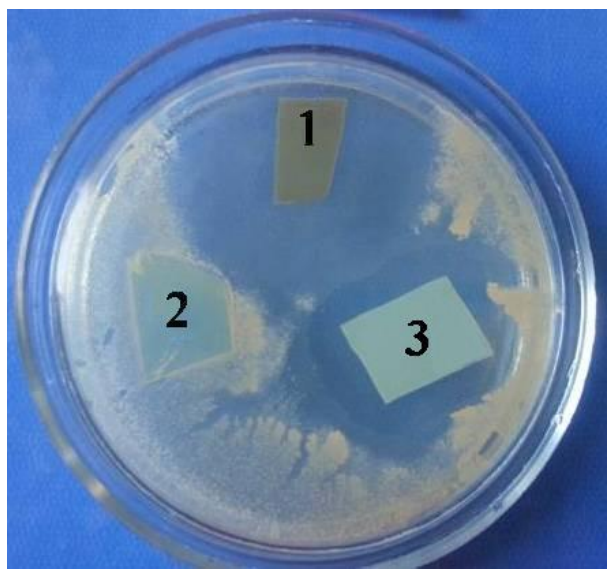

a)

\subsection{Microbiological Tests}

The results of microbiological studies of film material with tiamulin fumarate showed the absence of growth of the bacterial culture Staphylococcus aureus with the growth inhibition zone diameter of $50 \mathrm{~mm}$ (Fig. 9a, 1) and the absence of growth of the bacterial culture Escherichia coli (crops from under polymer materials) (Fig. 9b, 1), that was not observed in the study of polymer samples without tiamulin fumarate (Fig. 9a, 2 and Fig. 9b, 2).

The bactericidal activity of tiamuline fumarate in relation to the most widespread gram-positive and gramnegative bacteria was compared with the biological activity of Decametoxin, which has a pronounced bactericidal effect [13]. According to the results, the bactericidal activity of tiamulin fumarate is not inferior to the known Decametoxin (Fig. 9a, 3, Fig. 9b, 3).

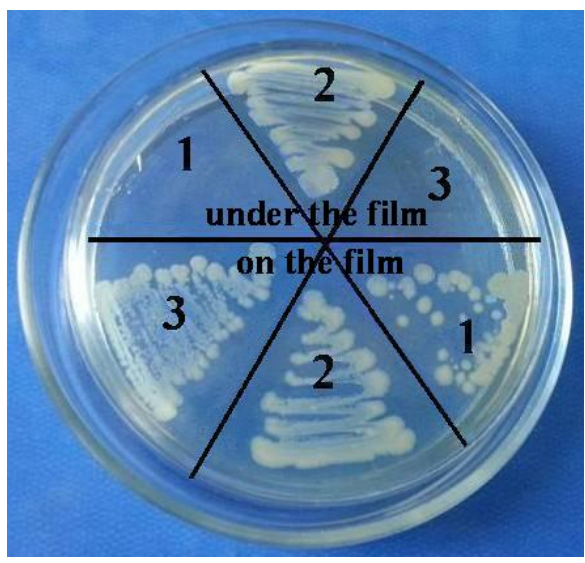

b)

Fig. 9. Effect of film materials with tiamulin fumarate (1) and without tiamulin fumarate (2) and film materials with decamethoxin (3) on the bacterial cultures Staphylococcus aureus (a) and Escherichia coli (b) 
Biological activity studies have shown that samples of the studied film materials with tiamulin fumarate have a biological action in relation to the test cultures of bacteria of Staphylococcus aureus and Escherichia coli, which was manifested by the lack of growth of microorganisms under samples and the presence of growth inhibition zones around the samples.

Thus, the film materials with tiamulin fumarate based on PUU with fragments of copolymer VP-VA and HMDA in the structure are biocompatible, capable to biodegradation with simultaneous release of tiamulin fumarate from a polymer matrix, which shows bactericidal activity. Therefore, they can be used for production of drainages in abdominal surgery.

\section{Conclusions}

The studies of the influence of the model biological medium on the structure and properties of hydrophilic PUU with fragments of copolymer VP-VA and macrochain extension HMDA in the structure and hydrophilic film materials on their basis with tiamulin fumarate were carried out. According to the results of physicomechanical tests, for film materials with tiamulin fumarate after their incubation in the BM 199 there is a decrease of the tensile strength and relative elongation at break, unlike in unfilled PUU. It is possibly due to the release of the drug substances tiamulin fumarate from the polymer matrix. The results of IR spectroscopic studies showed the changes of absorption bands of groups which are capable to form hydrogen bonds and a decrease of the intensity of the absorption band $v_{\mathrm{C}=\mathrm{O}}$ of vinylpyrrolidone ring. The obtained results testify to biodegradation of polymer materials under the influence of BM 199. By the tissue culture method, the absence of toxic effects of film materials with tiamulin fumarate on the cultured cells been has established. By the microbiological studies, the manifestation of bactericidal properties on the bacteria Staphylococcus aureus and Escherichia coli has been established. Considering the aforesaid, the studied biomaterials can be used for production of drainages in abdominal surgery.

\section{References}

[1] Galatenko N., Rozhnova R.: Biologicheski Aktivnye Polimernye Materialy dlia Meditsiny. Naukova dumka, Kyiv 2013.

[2] Mazur L., Rozhnova R., Galatenko N., Nechaeva L.: Dopov. Nats. Akad. Nauk Ukrainy, 2007, 5, 141.

[3] Rudenchyk T., Rozhnova R., Galatenko N., Kiselova T.: Voprosy Khimii i Khimicheskoy Tekhnologii, 2017, 5, 49.

[4] Rudenchyk T., Rozhnova R., Galatenko N.: Adv.Biochem., 2017, 5, 73. https://doi.org/10.11648/j.ab.20170504.14
[5] Rudenchyk T., Rozhnova R., Galatenko N., Kiselova T.: Visnyk Odes. Nats. Univ., 2016, 21, 67. https://doi.org/10.18524/23040947.2016.3(59).79591

[6] Stipkovits L., Varga Z., Laber G., Bockmann J.: Vet. Microbiol., 1984, 9, 147. https://doi.org/10.1016/0378-1135(84)90030-0

[7] Islam K., Klein U., Burch D.: Poult. Sci., 2009, 88, 2353. https://doi.org/10.3382/ps.2009-00257

[8] Rozhnova R., Ostapenko S., Galatenko N.: Naukovi Zapysky NaUKMa, 2010, 105, 32.

[9] Rudenchyk T., Rozhnova R., Kiselova T.: III Miznarod.

Zaochna Naukovo-Prakt. Konf. Molodykh Vchenykh

«Fundamentalni ta Prykladni Doslidzennia v Suchasnii Khimii», Ukraine, Nizhyn 2016, 111.

$\lceil 10\rceil$ Kedik S., Zhavoronok E., Sedishev I. et al.: Drug Develop. Regist., 2013, 2, 18.

[11] Pretsch E., Bëllmann P., Affolter C.: Structure Determination of Organic Compounds. Tables of Spectral Data. Springer-Verlag, Berlin Heidelberg New York 2000.

[12] Lebediev Ye., Konstantinov Yu., Galatenko N. et al.:

Toksykoloho-Hihiienichni ta Doklinichni Doslidzhennia Polymernykh Materialiv i Vyrobiv na ikh Osnovi Medychnoho Pryznachennia. Naukova dumka, Kyiv 2009.

[13] Xalieieva O., Pechenizka L.: Ukr. Biopharm. Zh., 2012, 3, 28.

Received: November 13, 2018 / Revised: December 12, 2018 /

Accepted: April 12, 2019

\section{ВИВЧЕННЯ БІОДЕГРАДАЦЇ̈, БІОСУМІСНОСТІ ТА БАКТЕРИЦИДНОЇ АКТИВНОСТІ ПЛІВКОВИХ МАТЕРІАЛІВ 3 ТІАМУЛІН ФУМАРАТОМ НА ОСНОВІ ПОЛІУРЕТАНСЕЧОВИН}

Анотація. Досліджено вплив модельного біологічного середовища 199 на структуру та властивості плівкових матеріалів з тіамулін фумаратом на основі поліуретансечовин, які містять у структурі гідрофільні фрагменти кополімеру $\mathrm{N}$ вінілпіролідону з вінілацетатом та вініловим спиртом. 3 а даними ІЧ-спектроскопії, під впливом біологічного середовища 199 відбуваються процеси біодеградації полімерних матеріалів, що супроводжуються зниженням інтенсивності смуги поглинання $v_{C=O}$ вінілпіролідонового кільия. Фізико-механічними випробуваннями встановлено, щзо введення тіамулін фумарату до складу поліуретансечовин сприяє їх біодеградачії про щчо свідчить зниження значень міџності (у 1,28-2,38 рази) та відносного подовження при розриві (у 1,36-1,82 рази) після інкубаиії у біологічному середовищі 199. Методом культури тканин встановлена біосумісність плівкових матеріалів 3 тіамулін фумаратом. За результатами мікробіологічних досліджень спостерігали прояв бактерицидних властивостей відносно бактерій Staphylococcus aureus ma Escherichia coli, щюо дає можливість використовувати їх для виготовлення дренажів в абдомінальній хірургї.

Ключові слова: поліуретансечовина, тіамулін фумарат, кополімер, $N$-вінілпіролідон, вінілачетат, вініловий спирт, модельне біологічне середовище 199. 